DOI: 10.2478/linpo-2013-0003

\title{
QUESTIONS IN LATVIAN AND POLISH PARLIAMENTARY DEBATES: A COMPARATIVE STUDY
}

\author{
JOANNA CHOJNICKA
}

\begin{abstract}
Joanna Chojnicka. Questions in Latvian and Polish Parliamentary Debates: A Comparative Study. Lingua Posnaniensis, vol. LV (1)/2013. The Poznan Society for the Advancement of the Arts and Sciences. PL ISSN 0079-4740, ISBN 978-83-7654-273-7, pp. 37-54.

This article examines the use and functions of questions in Latvian and Polish parliamentary debates from the perspective of comparative pragmatics. The research is based on a corpus of 200 utterances excerpted from transcripts of Latvian and Polish parliaments' sittings from 2009. It uses the typology of questions in interaction developed by ILIE (1999). The paper suggests that differences in the frequency and functions of questions reflect different degrees of interactionality of a debate, which is a genre that combines monologic and dialogic features. On this basis, the discourse of Polish parliamentary debates is recognized as more interactional than its Latvian counterpart.

Joanna Chojnicka, University of Konstanz, Zukunftskolleg, Konstanz, Germany, joanna.chojnicka@ uni-konstanz.de
\end{abstract}

\section{INTRODUCTION}

The present paper analyzes the uses and functions of questions in Latvian and Polish parliamentary debates from the perspective of comparative pragmatics. Additionally, the goal of this paper is to prove the applicability and usefulness of the discourse of parliamentary debates for linguistic and sociolinguistic studies, in which comparative research plays an important part. The discourse of parliamentary debates is believed to constitute a very useful and practical source of material for many reasons. As far as access to the research material is concerned, parliamentary sessions in many countries of the postmodern world are well documented with transcripts, audio and video recordings available on-line. The usefulness of Internet resources can hardly be overestimated: along with the study material - the political language in use - the World Wide Web provides many practical tools. For instance, the website of the Library of US Congress (http://thomas.loc.gov/home/LegislativeData.php?\&n=Record) offers the opportunity to search speeches by the MP's name (here and further: MP = member of parliament), which could prove invaluable in research on individual speech style (cf. JOHNSTONE 2009). Another reason is that parliamentary discourse is characterized by specific structural organization, "the recurrence of particular types of discursive activity", constraints of rules and expectations associated with public speaking and more specifically the Rules of Procedure, and "the distinctive inferential frameworks of specific institutional contexts" 
(KoESTER 2006: 4-5). These structures, genres, constraints and frameworks are shared by the discourses of parliamentary debates in different languages, what makes it possible to pick up corresponding elements for comparative research, as e.g. in ILIE 2010, which offers comparison of forms of address in the British Parliament and Swedish Riksdag.

This article puts forward the assumption that differences in the usage of questions reflect differences in the degree of interactionality of discourse. A debate is seen here as a genre of discourse that is both monologic and dialogic in nature, as it consists of turns whereby speakers react to previous turns and anticipate following turns (features of dialogue), but each turn is more than just a contribution to the dialogue - it is a speech, thus independent and interpretable on its own (features of monologue; cf. CHOJNICKA 2012: 69). Monologicality and dialogicality are thus not polar opposites whereby one excludes the other, but rather form a continuum. The more questions that allow an answer from another speaker (here called reaction requests) are asked during a debate and/or the more answers are actually provided by other speakers, the more dialogic and less monologic that debate is.

Before the material analysis may proceed, a technical remark is in order. There are two main differences in the way debates are conducted in the Polish Sejm and the Latvian Saeima which relate directly to the problem of using questions. First, while both institutions define a debate in a very similar way, the Polish variant includes an additional procedure of asking questions. Before every voting, one MP from each parliamentary club may submit a question. After receiving a list of MPs wishing to do so, the Chairperson decides how much time (distributed in an equal way among the speakers) is to be allowed for one question. ${ }^{1}$ This means that for every matter in the working order there might be as many questions as many clubs operate in Sejm. It may be assumed that due to this reason the frequency of using questions in the Polish parliament is much higher than in the Latvian parliament. Naturally, MPs of Saeima may also ask ministers or other officials questions, but they are a separate part of a parliamentary session.

Second, there are some disparities in the (written and non-written) codes of behaviour of the two institutions that influence a certain aspect of debate discourse. In the Latvian parliament, the speaker who holds the floor is not allowed to engage in an exchange of arguments with other MPs in the hall. It means that when a listener interrupts the speaker, he/she has basically no right to react. In turn, in the Polish parliament such events sometimes do occur. Also, there is a strong tradition to address other MPs indirectly in Saeima (i.e. in the third person - 'MP X has suggested...'). In Sejm, speakers much more often address their predecessor/opponent directly ('MP X, you have suggested ${ }^{2} .$. '). This matter may also have some impact on the frequency of using questions in a parliamentary sitting.

\section{METHODOLOGY AND CRITERIA FOR THE CLASSIFICATION OF QUESTIONS}

The present study is based on written transcripts provided by the Polish Parliament (Sejm) and the Latvian Parliament (Saeima) at their Internet home pages (www.sejm.gov.pl and www.saeima.lv, respectively). For each parliament, ten random sitting transcripts from

1 http://www.sejm.gov.pl/prawo/regulamin/kon7.htm, viewed May 16th 2010.

2 Actually, in Polish this kind of address involves a third person form (politeness form) which is used in official situations or by strangers, but it is still a direct form of address. 
2009 have been chosen. From each transcript, ten random fragments with questions have been excerpted - in most cases, the whole paragraph. This way a corpus of 100 examples for each language (200 for both) has been created, with an average of 1.545 questions per example.

For the needs of this study, a question in written discourse has been identified as a sentence closed with a question mark. The '?' symbol is used when searching for questions in the two corpora. As admitted by Camiciottoli, this procedure has certain disadvantages, but is sufficient to "clearly distinguish question forms" in vast majority of cases (CAMICIOTTOLI 2008: 1221).

Even though this analysis focuses on sentences formally identified as questions, much larger fragments of texts included in the corpus have been read carefully and considered in the investigation of selected examples. This method complies with the requirements of pragmatics, which emphasizes the role of context in the study of meaning or, in other words, studies "context-dependent aspects of meaning" (HORN \& WARD 2006: xi). This is especially relevant to the functional classification of question types (cf. 2.2).

\subsection{FORMAL CLASSIFICATION OF QUESTIONS}

All the questions in the study have been grouped according to certain formal criteria. The first dichotomy divides them into positive and negative questions on the basis of the properties of the verb. If the verb is negated, the question will be negative, if not - it will be positive. This division is necessary because negative questions in argumentative discourse are presumably more likely to have rhetorical functions.

Questions under consideration have also been classified according to the question word they begin with. This follows from the hypothesis that certain question words are associated with, and dependent on, specific question types.

Table 1 shows what types of questions have been distinguished and gives examples of question words for each type. Note that these are provisional labels rather than official terms. Also, the classification does not comply with any acclaimed typology of question words - e.g. maybe is hardly ever taken to be one.

Only examples found in the two corpora have been included in the table. Thus, a dash (-) does not mean that the respective language lacks a certain type of question, but that it is not represented in the material. An asterisk $\left(^{*}\right)$ means that the respective word is declinable; the table gives the nominative form, while in the material all other case forms are possible as well.

I have found 162 Polish and 147 Latvian questions (Tab. 2). They are divided into positive and negative (vertically) and the number of questions for each question type is provided (horizontally). The results are quite interesting. First, we may talk about certain similarities between the two discourses:

1. The number of negative questions is comparable (in sum, 24 for PL Sejm and 22 for LV Saeima).

2. The number of 'why' questions (inquiring about reasons for something) is almost identical (23 for PL Sejm and 22 for LV Saeima).

3. In both languages, the negative questions are confined to yes/no questions and 'why' questions. This will have certain implications further on. 
Table 1. Types of questions and their question words in the two corpora

\begin{tabular}{|c|c|c|}
\hline \multirow{2}{*}{ Types of questions } & \multicolumn{2}{|c|}{ Question words } \\
\hline & $\mathrm{PL}$ & LV \\
\hline yes/no & $c z y$; emph. $c z y \dot{z}$ & vai \\
\hline yes/no + or & $c z y \ldots, c z y(t e \dot{)}) \ldots$ & vai...,vai... \\
\hline why, for what reason etc. & dlaczego, сzети; еmph. wimię czego & kāpēc, kādēl \\
\hline what for & po co & kamdèl, kam \\
\hline what about (something) & $\operatorname{coz}($ czymś) & - \\
\hline how & jak, w jaki sposób & $k \bar{a}, k \bar{a} d \bar{a}$ veidā \\
\hline what/which (kind) & jaki/który* & $k \bar{a} d s *$ \\
\hline who & kto* & kgs $*$ \\
\hline what & co*; emph. cóż & kas \\
\hline when & - & kad \\
\hline where & - & kur \\
\hline 'maybe' & może & varbūt \\
\hline clipped questions & no verb, e.g. A pani? 'And you?' & $\begin{array}{l}\text { no verb, e.g. Un jūs? } \\
\text { 'And you?' }\end{array}$ \\
\hline
\end{tabular}

Second, the most relevant dissonance in this comparison is the fact that Polish seems to be much less diversified when it comes to question types:

1. Interestingly enough, there were no questions about time ('when') and place ('where') in the Polish material.

Table 2. Number of questions for each question type in the two corpora

\begin{tabular}{|l|c|c|c|c|}
\hline \multirow{2}{*}{ Types of questions } & \multicolumn{5}{c|}{ Number of questions } \\
\cline { 2 - 5 } & \multicolumn{2}{|c|}{ PL (162) } & \multicolumn{2}{c|}{ LV (147) } \\
\cline { 2 - 5 } & pos & neg & pos & neg \\
\hline yes/no & 48 & 19 & 21 & 14 \\
\hline yes/no + or & \multicolumn{2}{|c|}{6} & \multicolumn{2}{c|}{4} \\
\hline why, for what reason etc. & 18 & 4 & 16 & 6 \\
\hline what for & 2 & 0 & 2 & 0 \\
\hline what about (something) & 3 & 0 & 0 & 0 \\
\hline how & 15 & 0 & 9 & 0 \\
\hline what/which (kind) & 17 & 0 & 10 & 0 \\
\hline who & 3 & 0 & 37 & 0 \\
\hline what & 15 & 0 & & 0 \\
\hline when & 0 & 0 & 3 & 0 \\
\hline where & 0 & 0 & 9 & 0 \\
\hline no question word & 0 & 0 & 5 & 1 \\
\hline 'maybe' & 1 & 0 & 5 & 0 \\
\hline clipped questions & 2 & 0 & 1 & 0 \\
\hline other & 8 & 0 & 4 & 0 \\
\hline
\end{tabular}


2. There were no questions without question words, which is in contrast to colloquial spoken Polish. ${ }^{3}$

3. Questions beginning with the modal marker (adverb) 'maybe' were much less frequent in the Polish than Latvian material.

These results are summarized in the Table 2.

These differences may be partially explained by phraseological variation. For example, the English question what about the childhood dreams? (what has happened to, has become with the childhood dreams?) may be translated into Polish as co z marzeniami dziecinstwa ('what about' question type) and into Latvian as kur ir (palikuši) bērnības sapñi ('where' question type). However, other variants are also possible, and it is impossible to make valid conclusions on the basis of a small corpus. A study of translations (from one language into the other or from a third language into both) could be useful in determining this issue.

\subsection{FUNCTIONAL CLASSIFICATION OF QUESTIONS}

Ilie proposes a dichotomy of standard and non-standard questions. Information-eliciting, answer-eliciting, action-eliciting and mental response-eliciting questions are subtypes of the former. Rhetorical, expository and echo questions are subtypes of the latter. Non-standard questions are also divided in terms of argumentative orientation into argument-eliciting, argument-prefacing and argument-supplying questions (ILIE 1999: 975).

This classification may serve as a base for the functional distinction of questions in the present study. However, it needs to be modified. The main reason for this is that standard questions are not frequent in parliamentary debates, since they are associated with more interactional discourses (e.g. lectures, discussions, doctor-patient dialogues). All standard questions (true interrogatives), then, will be grouped under one heading of reaction request (as providing information, answer, action or mental response is always a kind of reaction). It is assumed here that this reaction is expected to come from another person (not the speaker who asks the question).

Non-standard questions (which are of more interest to this study), on the other hand, are speaker-oriented rather than audience-oriented, as the speaker who asks them is the one to react (e.g. provide the answer or a comment). They will be divided into assertive, tokeninformation, expository, echo and rhetorical questions.

Assertive questions have the form of questions (reinforced by syntax, e.g. word order, and raising intonation, or a question mark in writing) but their function is to present some kind of assertion in a more or less explicit fashion. Assertive questions may be used as expressions of two basic speech acts: suggestion and evaluation. It seems relevant to distinguish very strong evaluative questions under the heading of accusatory questions.

Token information questions are those that "pretend" to request for information (often from a specific speaker or source) and implicate a negative attitude, negative assessment of the party that the question is meant for.

3 In both Latvian and Polish, the question word for yes/no questions (LV vai and PL czy) may be dropped in spoken discourse, e.g.:

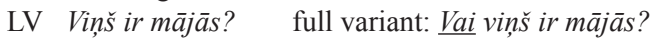

PL Jest $w$ domu? full variant: $\underline{C z y}$ (on) jest $w$ domu?

'Is he at home?' 
Another category is what ILIE (2010) calls expository questions. They are used to present a problem, introduce a topic, predict an upcoming argument. In a way, an expository question may be seen as request for information, because no argument or assertion is implicated in the question itself; on the other hand, it is by default answered by the speaker who has asked it and no response from the audience is actually expected.

Ilie's echo questions may be relevant for expository questions in the way that the speaker who wishes to respond to another MP's question often simply repeats it before answering it. This way it is both an echo and expository question.

Differences between the types introduced above may be presented schematically as follows:

$\begin{array}{lll} & \text { the claim follows } & \text { the claim is expressed } \\ \text { the question } & \text { in the question } \\ \text { claim of fact } & \text { expository, echo } & \text { assertive } \\ \text { claim of opinion } & \text { token-information } & \text { evaluative }\end{array}$

The last category - rhetorical questions, in order to be understood properly, must be defined against the other categories, especially the accusatory type. As will be seen later, these two kinds share a lot of common properties and often are difficult to tell apart.

It has been mentioned above that it is the question-asking speaker who provides (or is expected to provide) reaction to his/her own non-standard question. Three types of reactions have been distinguished:

1. direct answer,

2. follow-up (when the speaker comments or elaborates on the topic introduced or suggested in the question),

\section{3. a pause.}

It is expected that rhetorical questions will be followed by a pause - or, in other words, left unanswered ${ }^{4}-$ while e.g. expository questions will be followed by an answer.

The use and functions of questions depend on the genre of parliamentary discourse in which they occur. In the template utterances of the Chairperson (i.e., the ready-made formulas associated with the Chairperson's function as a conférencier, cf. CHOJNICKA 2012), the question form is as predictable as the statement form - that is, there are some tailored interrogative constructions to choose from, and normally their function is to request information, i.e. the Chairperson does not know the answer and expects it to be given and be true:

$$
\begin{aligned}
& \text { PL Czy ktoś z pań i panów postów chciatby jeszcze dopisać się do listy postów } \\
& \text { pytajacych? [2009-03-18] } \\
& \text { Would any of you ladies and gentlemen still like to sign the list of asking MPs? }
\end{aligned}
$$

4 In a corpus of written transcripts, it is of course rather difficult to recognize pauses, unless the transcripts' authors have decided to mark them in a particular way. In the transcripts of Latvian parliamentary debates, each contribution is divided into paragraphs separated by an empty line. If a question is followed by an empty line and then a topic shift occurs, it is likely that a pause did in fact occur. In the transcripts of Polish parliamentary debates, on the other hand, each contribution forms one continuous paragraph, regardless e.g. of topic shifts. It is thus impossible to recognize pauses here. For this reason, pauses are not features on the basis of which rhetorical questions are distinguished from other types, but are solely comprised in their characterization. For distinguishing features of rhetorical questions, see section 3.6. 
LV Vai Pieprasījumu komisijas vārdā deputāts Brigmanis vēlas ko teikt? [2009-0528]

Does MP Brigmanis wish to say something on behalf of the Submissions committee?

During a debate, on the other hand, asking for information is expected to be much less common. When a debate starts, questions become likely to be employed for the purposes of argumentation and persuasion, since they are embedded in argumentative and persuasive discourse. Requesting information reveals a kind of uncertainty or lack of knowledge which is not the effect a speaker wants to achieve. Instead, interrogative forms are used to express suggestions (e.g., 'Why don't we vote "for"?') or "smuggle" assertions (e.g. 'Why shall we pay more?'). Also, questions may convey negative assessments (e.g. 'Whoever voted “against"?') and introduce new topics or problems (e.g., 'What is a progressive tax?'). In none of these uses do they require an answer from the audience. In fact, they are usually followed by a kind of response, clarification or explanation from the same speaker who has asked them.

Not all of these questions may be called rhetorical, though. Questions that do not require an answer because it is irrelevant or obvious ${ }^{5}$ must be distinguished from questions answered by the speaker who has asked them, even if he/she does it indirectly (CAMiciotToLI 2008: 1223). A rhetorical question is usually followed by a longer pause (or, in fact, ends the debate turn) and is supposed to "hang in the air" for the listeners to consider. The speaker already knows what the answer is (REXACH 1998: 143) - so, it may be interpreted as a kind of challenge, provocation.

My assumption is that if defined this way, rhetorical questions in both parliaments will be rather rare. Similarly, information questions sensu stricto will appear rather occasionally. Speakers will more often employ "token" requests for information in order to appear to be engaging in an exchange of opinions between equal participants.

Rhetorical questions and reaction requests (standard questions) will be seen as two extremes of a continuum: "the less a question is perceived as a speaker's request for information or for an answer, the more it tends to become an expression of his/her personal views" (ILIE 1999: 987).

It must be kept in mind that the format of a parliamentary debate, in a way, excludes reaction requests. First, a debate requires the participants to voice their opinion on a given topic. The topic is almost never introduced in a question form, but it may be seen as a question - or problem - to be responded to. MPs who take part in the debate are expected to talk when they know (or think they know) the answer or the solution. Every debate turn, thus, is a "micro-speech" delivered by the MPs "one by one". It is not like a discussion where every participant has the same right to ask, to answer, and to react to what has been said earlier.

Second, MPs rarely ask standard questions because there is little chance that they will be responded to immediately. A question asked somewhere in the middle of a 5 minute-long speech may easily be forgotten. Besides, there is a strict order of MPs speaking, so the person that the question is meant for may be unable to answer it during the respective debate - and it is not allowed to get back to it when the debate is announced finished.

Camiciottoli's formulation that rhetorical questions do not require an answer because it is irrelevant or non-existent is a bit too restrictive in my view. 
In the following sections we will analyze questions from the corpus grouped according to their functional type and see if the dissonances between Polish-Latvian question words are of any relevance to this distinction.

\section{STUDY RESULTS}

\subsection{AUDIENCE-ORIENTED QUESTIONS}

ILIE's (2010) "standard" questions or reaction requests (audience-oriented questions), as predicted, are rather rare in the debate turns: 24 per cent for the Polish and 5.6 per cent for the Latvian parliament.

The fact that the number for PL Sejm is over four times higher than for LV Saeima may be explained by the question-asking part of the debate described in Section 1. The difference would be much more significant, though, if the questions from the Polish material were chosen completely at random. Instead, special care has been taken to avoid the question-asking part of the debates and excerpt examples from the debates proper.

Three main types may be distinguished: requests for information (e.g. (3), (4)), suggestions and requests for confirmation (5). Reaction requests are normally positive - the exception being a suggestion question ((6)-(7)). Such questions usually induce a follow-up or end a speaker's turn.

PL Mam pytanie do posła sprawozdawcy: Czy w porzadku prawnym innych państw europejskich, w których obowiazuje klubowy zakaz stadionowy, funkcjonuje tryb odwoławczy, czy go nie ma? Dziękuje. [2009-01-21]

I have a question to the reporting MP: Is there in the law order of other European countries, which have club stadium bans, a mode of appeal or is there not? Thank you.

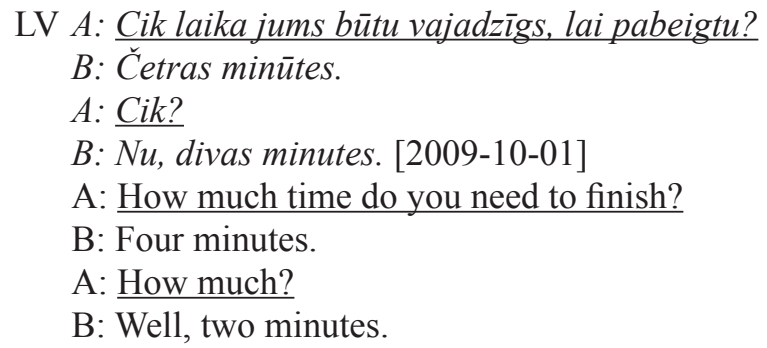

In example (4), the first question is a request for information that the Chairperson asks the current speaker. The second question is ambiguous: it may be interpreted as a confirmation request, but the speaker apparently interprets it as a kind of reproof, because he/she changes the original answer into something that he/she expects the Chairperson to approve more. Example (5) is a more typical request for confirmation:

PL Czy pan minister daje gwarancje, że taka sytuacja, jakby odzyskiwania tych danych $i$ wykorzystywania ich - być może czasami nawet do działalności przestępczej - nigdy nie nastapi? Dziękuję. [2009-05-20] 
Does the minister guarantee that such situation of the data being kind of reclaimed and used - maybe even sometimes for criminal activity - will never happen? Thank you.

Audience-oriented suggestions differ from speaker-oriented suggestions because the former are direct and should be understood literally (e.g. (6), (7)) while the latter are indirect and the suggestion is implicated, not provided in the literal wording (8):

PL Czy nie należałoby zamienić słowa 'uprawniony' na 'zobowiązany'? [2009-0121]

Shouldn't the word 'entitled' be changed into 'obliged'?

LV Bet kāpēc gan negriezties valdībā, konkrēti, Tieslietu ministrijā? [2009-06-04] But why not to turn to the government, specifically, the Ministry of Justice?

LV Vai Latvijā mums ir vajadzīga iestāde ar tādu vadītāju, kurš nemākulības vai varbūt pat launprātības dēl cenšas iznīcināt Latvijas valsts valodu? [2009-0129]

Do we need an institution in Latvia with such a head, who due to (his) inefficiency or even maybe malevolence tries to destroy the Latvian state language?

The underlying suggestion in this question is that the director of the institution should be made redundant - even though it is not stated explicitly. Additionally, the question is a very strong negative evaluation of the director, which is reinforced by the use of evaluative expressions - nemākulība 'inefficiency', l,aunprātība 'malevolence', iznīcināt 'to destroy'. More on this kind of questions follows below.

\subsection{EXPOSITORY QUESTIONS}

Expository questions are used to introduce a topic or predict an argument. They occur "in connection with topic shifts", work to focus on an issue or problematize it, "their function is to address the audience and foreshadow information about the topic to be discussed" (ILIE 1999: 980). They do not contain any implicit assertions or evaluative phrases - thus, they do not implicate the speaker's attitude. It may be said that when asking an expository question, the speaker temporarily assumes the role of his/her own interlocutor, as if a constructed speaker were actually putting forward a sincere reaction request, asking for information he/she does not know. This way, expository questions generate the impression that a dialogue is taking place within the speaker's monologic contribution (cf. TANNEN 1986 on constructed dialogue). This is confirmed by the study results: all expository questions in both corpora are followed with an answer by the same speaker, for example:

LV Ko man apliecina valdība un Finanšu un kapitāla tirgus komisija? To, ka šis likums nav unikāls. [2009-02-12]

What do the government and the Finances and capital market committee confirm to me? That this law is not unique.

Expository questions are more frequent in the Latvian material (20.8 per cent) than in its Polish counterpart (12.6 per cent). There are no negative expository questions found. 
A kind of subtype of an expository question is an echo question:

PL Pan poset Szlachta pyta o bardzo ważna sprawe kosztów. Czy wzrośnie liczba wniosków, czy się zmniejszy w sądach wieczystoksięgowych? [2009-02-18]

MP Szlachta asks about the very important issue of costs. Will the number of applications increase, or will (it) decrease in the mortgage register courts?

In this example, the use of an echo question is confirmed with the introductory sentence that refers back to the original question. However, not always is the use of echo so obvious. Sometimes only the context - i.e., the fact that a certain question has been uttered by someone else before, and that the current speaker relates to its theme in his/her speech - proves the occurrence of an echo question.

There is one aspect of expository questions unique to the Polish corpus. The answer that follows such a question is often introduced with a discourse marker otóż. While PolishEnglish dictionaries translate it as 'well' or 'now', these translations do not do justice to the interactional, dialogic nature of this marker. Its occurrence with expository questions speaks in favour of interpreting them as cases of constructed dialogue. An example of the use of otóż follows below:

PL Na czym polega istota zmiany tej ustawy? Otóż obecnie koszty dojazdu lekarzy weterynarii sa opodatkowane podatkiem dochodowym. [2009-04-21]

What is the point of the change of this law? Well now the costs of transport of vets qualify for the income taxation.

Special kind of expository questions are those that introduce a subjective opinion of the speaker (rather than a claim of objective fact). Two of such interrogatives have been found in each corpus. In all four cases, if the question is positive - the opinion is negative, and the other way round, e.g.:

LV Vai tad šodien mūsu skolotāji strādā kaut kādos īpaši labvēlīgos apstākḷos? Nē. Un vēlreiz nē! [2009-10-01]

Do our teachers today work in some kind of especially beneficial conditions then? No. And once again no!

It may be argued that this example is ambiguous: it has some properties of an assertive question (evaluative phrases used ironically - ipaši labvēlīgos apstākl,os 'in especially beneficial conditions') and even of a rhetorical question (it relates to something obvious, provokes one possible answer). It has been classified as an expository question because the answer provided by the speaker seems to be constructed as a sincere reaction to request for information - but if one uses different criteria, other interpretations are also possible.

\subsection{TOKEN INFORMATION QUESTIONS}

As mentioned above, token information questions are questions that "pretend" to inquire for information, in reaction to which the speaker offers his/her own opinion, assessment, evaluation. As indirect expressions of speaker assessment, token information questions belong to the group of pragmatic face-saving devices, where 'face' is defined as 'the 
positive social value a person effectively claims for himself" (SCHIFFRIN 1994: 102, quoting GOFFMAN 1967); see also 3.5.

The frequency of using such questions is, surprisingly enough, almost equal in both corpora (see Tab. 3). However, if we count in examples which are ambiguous, the numbers get more diverse: 32 per cent for Polish and 26.4 per cent for Latvian.

On the surface, token information questions do not contain any evaluation/assessment phrases themselves. However, they are normally followed (e.g. (13)) or sometimes preceded (e.g. (14)) by a kind of statement that makes the stand of the speaker clear. Thus, the proper interpretation of such interrogatives is context-dependent.

Table 3. Token information and ambiguous questions in the two corpora

\begin{tabular}{|l|r|r|}
\cline { 2 - 3 } \multicolumn{1}{c|}{} & PL & LV \\
\cline { 2 - 3 } \multicolumn{1}{c|}{} & \multicolumn{2}{c|}{$[\%]$} \\
\hline token information & 24.66 & 24 \\
\hline token information/rhetorical & 2 & 0 \\
\hline token information/evaluation & 2 & 2.4 \\
\hline token information/suggestion & 3.33 & 0 \\
\hline in sum & 32 & 26.4 \\
\hline
\end{tabular}

PL Jak to świadczenie mieści się $w$ systemie polskiego prawa $w$ kontekście emerytur, $w$ kontekście ewentualnych innych świadczeń? W moim przekonaniu to, na co dzisiaj wystawiacie polskich nauczycieli, to jest coś, co nie mieści sie w systemie polskiego prawa. [2009-04-21]

How does this benefit fit into the Polish law in the context of pensions, in the context of possible other benefits? I am convinced that what you put Polish teachers to today is something that does not fit into the Polish law system.

LV Diemžèl solidaritāte mūsu valstij izmaksā pārāk dārgi. Ko tad mūsu Nacionālie bruņotie spēki kopš 2003.gada dara tajā valst̄̄? Kādus mērḳus viņi tur cenšas sasniegt un kādus jau ir sasnieguši? [2009-05-21]

Unfortunately, solidarity costs too much for our country. What, then, have our national armed forces been doing in that country since 2003? What goals are they trying to achieve and what have they already achieved?

Some token information questions give two possible alternatives ('yes/no + or'). In the question itself both possibilities are equally valid. There is no hint at the preference of the speaker - it only follows in the next utterance:

PL Czy intencja projektu jest realne zmniejszenie fiskalizmu, czy działanie czysto populistyczne? Bo czyż nie populizmem pachnie tak mało znaczaca dla obywateli zmiana? [2009-01-07]

(What) is the intention of this project - actual descrease of fiscality or simply populistic action? Because doesn't such a change, insignificant for the citizens, smell of populism? 
What is interesting about this example is the fact that the expression of the speaker's assessment takes place in another question. This question is assertive - evaluative (consider populizmem pachnie '(it) smells of populism'), that is why it may be classified as a statement of speaker attitude. The assertiveness of this question is reinforced by the conjunction bo ('because') - which is normally expected in statements (especially answers to 'why' interrogatives).

A similar example has been found in the Latvian material, but here the speaker attitude precedes the question. Actually, there are two 'yes/no + or' interrogatives, but the second one is graphically divided into two separate sentences:

LV Es domāju, ka tiesību nevar būt par daudz, bet pienākumu mūsu jauniešiem vajadzètu daudz vairāk (...) Vai drīkst palūgt viņu paņemt to papīriņu un izmest vai nedrīkst? Vai tā ir cilvēktiesību ievērošana, ja es, kā jau skolotājs, lieku viniem mājasdarbus pildīt? Vai nedrīkstu es to darīt? [2009-10-01]

I think that there shouldn't be too many rights, but our youngsters could have more obligations (...) Can he be asked to take that piece of paper and throw it away or can't? Is it observance of human rights if I, as a teacher, make them do homework? Or am I not allowed to do it?

Another group of token information questions are short interrogatives of the following type:

LV Par ko jūs te debatējat? [2009-04-30]

LV Un par ko ir runa? [2009-03-12]

PL O co chodzi? [2009-01-21]

PL O czym pan mówi? [2009-05-06]
What are you debating on here?

And what is the matter about?

What is going on?

What are you talking about?

Such questions clearly indicate that the speaker evaluates negatively what is happening, even if they remain unanswered.

\subsection{ASSERTIVE QUESTION - SUGGESTION}

"Non-standard" suggestions (the difference between standard and non-standard ones has been explained in 2.2) are surprisingly rare in both discourses: they constitute only 5.33 per cent of the Polish and 5.6 per cent of the Latvian examples. An example from Latvian has been given above in (8). Below an example from Polish is provided:

(21) PL Nie mam na myśli tego, żeby uczniowie z 4 klasy podstawówki ćwiczyli z licealistami, ale jeśli się zawiązuje jakaś grupa, do której zgłaszają się uczniowie 1, 2, 3 klasy liceum, to co szkodzi taka grupe uruchomić? [2009-03-31]

I am not thinking about pupils from fourth grade primary school exercising together with high school students, but if there is a group that students from first, second, third grade of high school sign for, then what is wrong about starting $\underline{\text { such a group? }}$

I have classified the 'what/how about (something)' interrogatives as suggestion questions. As predicted, the Latvian equivalent to the Polish co z... ('what with', 'what about') 
is kur ('where'). Interestingly enough, both corpora have returned one utterance of this type each, with very similar structure:

PL Spóźnione zadośćuczynienie (...) dotyczy tylko rodzin ofiar wystapień zbiorowych enumeratywnie wymienionych $w$ projekcie. Należy jednak zapytać, co w takim razie z zadośćuczynieniem dla rodzin pojedynczych ofiar zbrodni komunistycznych?

Co np. z zadośćuczynieniem dla matki ks. Jerzego Popietuszki? Co z zadośćuczynieniem dla rodziny upamiętnionego niedawno przez Sejm Ryszarda Siwca? [2009-03-18]

Delayed compensation (...) applies only to families of victims of collective unrests enumerated in the project. One has to ask, though, what then about compensation for families of single communistic terror victims? What for example about compensation for the mother of priest Jerzy Popiełuszko? What about compensation for the family of Ryszard Siwiec, recently commemorated by the Sejm?

(23) LV Nu tad būsim korekti un neteiksim tā vienkārši un vispārīgi: "Pareizticīgie un vecticībnieki svin tā!’” Un kur tad paliek citas Pareizticīgās Baznīcas? Kur tad paliek Austrumu ortodoksālo Rumānijas, Bulgārijas (...) Baznīcas? (...) Ja š̄̄s draudzes svin Ziemassvētkus pēc Gregora kalendāra, tad tagad, ja mēs likumā ierakstām: "Pareizticīgie un vecticībnieki - visi pār vienu kārti!", kur šeit paliek kaut kāda elementāra logika un cilvēktiesības? [2009-09-10]

So let us be correct and not say so simply and generally: "Orthodox and Old Believers celebrate like this!" And where then goes other Orthodox churches? Where then goes Eastern Orthodox Romanian, Bulgarian (...) churches? (...) if these congregations celebrate Christmas according to the Gregorian calendar, then now, if we write in the bill: "Orthodox and Old Believers - all in one way!", where here goes any elementary logic and human rights?

In both examples speakers criticize a project because it excludes certain parties. In (22), the speaker speaks against restricting compensation for families of collective unrest victims because he/she finds it unfair; in (23), the speaker speaks against making the Orthodox Christmas an official holiday, because then the members of all the other churches in Latvia would feel cheated out. Each of the questions separately suggests who should be also taken into account if the project in question is to be accepted; as a whole, the two strings of questions form an argument against the project.

\subsection{ASSERTIVE QUESTION - EVALUATION/ACCUSATION}

An evaluative or accusatory question is yet another device used when the speaker wishes to express strong disapproval or disagreement. It differs from token information and suggestion interrogatives in that it contains actual evaluative phrases (either in the question itself or in the immediate context). As a result, the speaker takes full responsibility for the impression his/her words make on the audience. While other types of non-standard questions might be considered face-securing because they present a proposition as barely a possibility, most of evaluative interrogatives presuppose it to be true (the evaluative phrase is underlined): 
PL Dlaczego żeście się dali tak tatwo sprzedać polskim liberałom w postaci Platformy Obywatelskiej? [2009-04-21]

Why did you let yourselves be sold so cheaply to the Polish liberals of the Civic Platform?

This question presupposes it as a fact that the addressees let themselves be sold cheaply to the Civic Platform. At the same time this is the content and target of the speaker's judgement. The question formally inquires for a reason for such a state of affairs, but does not require an answer since the true intention of it is merely to express the speaker's disapproval.

The amount of such questions in the two corpora varies greatly - it's 27.2 per cent for Latvian and 18 per cent for Polish. Note the inversely proportional correlation of these numbers to the rates for reaction requests $(24$ per cent in the Polish and 5.6 per cent in the Latvian material). I believe that these results are interrelated and point to an important disparity between the two parliaments: MPs of the Latvian one tend to be more direct in voicing their judgements and engage in interactional discourse (which triggers the use of response requests) much less freely.

Another aspect of the use of evaluative interrogatives is common to both languages: in almost all cases, they occur in two forms: 'yes-no' and 'why' question types. The latter type presupposes a proposition as a state of affairs; the answer is irrelevant since asking for a reason functions as a kind of motivation for bringing the issue about.

The former type behaves slightly differently: the speaker presents his/her judgement as one possibility, but the expected answer is imposed. On the surface of it, such a question is face-securing since it does not commit the speaker to any claim; on the other hand, the expected answer - which is always opposite to the value in the question - is apparent:

LV Vai Saeimas opozīcijas lielāko saucēju prasības pēc Saeimas atlaišanas nav bijuši tikai populistiski mēginājumi iegūt popularitātes punktus, šodienas ekonomiskās krīzes apstākḷos nekaunīgi izmantojot iedzīvotāju sarūgtinājumu? [2009-02-12]

Were not the demands to dissolve Saeima (made) by the biggest shouters of Saeima opposition only populistic attempts to gain popularity points, shamelessly using the inhabitants' bitterness in today's crisis conditions?

This example is negative, so the imputed answer is positive - yes, the demands were only populist attempts to gain popularity points.

This property is also typical of rhetorical questions, which makes the two kinds difficult to tell apart. Note that it is also shared by another phenomenon studied by pragmatics - irony (cf. Bryant \& Fox Tree 2002; Kreuz 2000).

In Latvian, evaluative questions often lack question words, which makes them identical to assertive sentences syntactically - the only interrogative marker is a question mark, which represents raising intonation:

LV Draugi mīlie! Un jūs tagad ar ticības masku galvā gribat mums iestāstīt, ka notiks integrācija? Mulkības! [2009-02-12]

Dear friends! And you now with the mask of faith on your head want to persuade us that integration will happen? Nonsense!

Another interesting difference between the two languages is that we may talk about an 
opposition of inclusive/exclusive evaluative interrogatives in Latvian; in Polish, this opposition is neutralized (naturally, there are exceptions, like example (24) which is exclusive with regard to the speaker). Inclusive evaluatives are aimed at all MPs in the Saeima, also the speaker who - on behalf of him/herself, his club, his party, or all the people with the same views - takes responsibility for the situation:

LV Ko tad mēs gribam no mūsu uzn̦ēmējiem, no tiem, kas maksā nodokḷus mūsu valstī? Vai mēs gribam sarežğìt viņiem dzīvi arī turpmāk vai negribam sarežğgît? [2009-04-30]

What do we want then from our entrepreneurs, from those that pay the taxes in our country? Do we want to complicate their lives also further or we don't want to complicate (it)?

Using an exclusive question, the speaker distances him/herself from those responsible, indicating that he/she does not belong to them and this "innocence" gives him/her the right to judge.

\subsection{RHETORICAL QUESTIONS}

Rhetorical questions, similarly to information requests, are usually short (one unexpanded clause), contain no evaluatives and are followed by a pause, which appears to make space for answer from the audience. However, the answer is actually not expected, as the pause is made solely for dramatic effect. Also the shortness of these formations contributes to the dramatic effect - sharp, abrupt questions followed by silence are supposed to startle the audience like unexpected noise. Rhetorical questions should be interpreted as "strong assertions" (REXACH 1998: 141) that, like evaluative questions, assume an answer which is opposite to the question value (positive question $\rightarrow$ negative answer, negative question $\rightarrow$ positive answer).

The amount of rhetorical questions in the two languages is very similar: 5.33 in Polish and 6.4 in Latvian. It confirms my assumption that they will be rather rare in this kind of discourse.

(28) PL Wydawałoby się, że projekt ustawy chciałby uprościć życie. Kto nie chciatby uprościć sobie życia? [2009-05-20]

One could think that the draft law wanted to simplify life. Who would not like to simplify life?

PL Pani poseł Bartuś mówiła, że nasza sejmowa komisja (...) nic nie dodała poza przecinkiem. Bo przepis jest dobrze sformułowany - cóż wiẹc miała dodawać? [2009-03-31]

Mrs. Bartuś said that our parliamentary committee (...) did not add anything but a comma. Because the regulation is well formed - what should it have added $\underline{\text { then? }}$

The Polish rhetorical questions are quite diversified in terms of question words - they can go with kto, czy, jak, ile etc. The Latvian ones, however, tend to combine most freely with kas* ('who', 'what') or kurš* ('which one', in many contexts interchangeable with $\left.k a s^{*}\right)$. 
(30) LV Ko lai padara? [2009-05-21]

What can be done? What can we do?

LV Ko lai dara? [2009-09-10] What can be done? (i.e. 'It can't be helped.')

(32) LV Kamdēl runāt patiesību? [2009-01-29]

Why to speak the truth?

(33) LV Kā tad šiem laudìm izdzīvot? [2009-06-04]

How should these people survive?

LV Kurš noteiks, kas ir liels? [2009-12-17]

Who will define what is big?

A rhetorical question is a strategy which reflects very neatly the double-monologic and dialogic - nature of a debate turn. A debate turn is a contribution to, a part of a larger entity, and at the same time a speech, comprehensive and independent. Rhetorical questions are interactional by default, as any interrogative; they anticipate the presence of, and address, a hearer, an audience. However, they do not require this audience, they make it irrelevant. It may be ventured to say that rhetorical questions are actually the least interactive of all kinds presented here. No rhetorical question has been found to provoke a response from the audience, even though it happens with other assertive questions - e.g. evaluatives:

PL A: Komisja dryfuje bez ładu, niczego nie odkryła, niczego nie objawiła i pewnie do niczego nie dojdzie. Bo jak można coś ukazać, skoro poczęcie nasteppuje w stanie politycznego zaślepienia?

The committee drifts without order, hasn't discovered anything, hasn't announced anything and will probably reach nothing. Because how can anything be shown if the conception takes place in a state of political blindness?

\section{B: Kto to panu pisat?}

Who wrote you that?

It may be due to the fact that rhetorical questions allow only one possible answer, and this is understandable for all hearers. Thus, they present a kind of statement, a kind of opinion, express speaker attitude, show where the speaker stands on a given matter - but they exclude discussion or disagreement. In fact, a discussion would be pointless because rhetorical questions are concerned with truisms, they are empty in the way that they do not add to the development, unfolding of the topic.

Pathos and seriousness are components of the effect of almost every rhetorical question. The use of rhetorical interrogatives makes the issue appear important, urgent, not to be dismissed.

\section{CONCLUSIONS}

In this study, I have analyzed the following types of questions:

- reaction requests - standard interrogatives which demand a reaction from the audience, 
- expository questions - always followed by an answer from the same speaker,

- token information questions - that appear to ask for information and convey negative speaker attitude,

- suggestion questions - that express suggestions in an indirect way,

- evaluative/accusatory questions - express speaker's judgement,

- rhetorical questions - used to achieve a dramatic effect, concerned with truisms and imposing only one possible answer.

These question types form a continuum in terms of two features: assertiveness and interactionality. Reaction requests are the least assertive (they do not contain a thesis and do demand response) and the most interactive (the response must come from another speaker). Rhetorical questions are the most assertive and the least interactive (in the corpus, they never provoke a response from the audience). Judging from the fact that there are much more reaction requests in the Polish than in the Latvian corpus (24\% and 5.6\%, respectively), it may thus be concluded that Polish parliamentary debates are more interactional: speakers ask more standard questions and expect answers for them which are often provided by the following speakers. In Latvian debates such situations are uncustomary: debate turns are more independent from each other, resembling speeches more than discussion contributions.

One of the aims of this study has been to see if there are any correlations between question word types/negative value of questions and their functional types. For this purpose a table has been created which is presented below. The table suggests that:

- expository questions tend to be positive,

- Latvian evaluative questions have the strongest tendency to be negative,

- some types tend to employ similar question words in both languages (reaction requests, token information and evaluative questions),

- Latvian, but not Polish, rhetorical questions have a "specialized" question word $\operatorname{kas}^{*}\left(k u r \check{s}^{*}\right)$.

Table 4. Comparison of question types in Latvian and Polish

\begin{tabular}{|c|c|c|c|c|c|}
\hline Function & Lang & Question words & Follow-up? & Neg & $\%$ \\
\hline \multirow{2}{*}{ reaction request } & PL & $c z y, j a k i^{*}, j a k(2)$ & follow-up (6), no (10) & 5 & 24 \\
\hline & LV & vai, kāds*, cik (2) & follow-up 1 , no (the rest) & 1 & 5.6 \\
\hline \multirow{2}{*}{ expository questions } & PL & various & answer $(100 \%)$ & 0 & 12.66 \\
\hline & LV & various & answer (100\%) & 0 & 20.8 \\
\hline \multirow{2}{*}{ token information } & PL & czy, dlaczego, jak + others & follow-up $(2 / 3)$, no $(1 / 3)$ & 7 & 24.66 \\
\hline & LV & vai, kāpēc, kas*+others & follow-up (2/3), no (1/3) & 2 & 24 \\
\hline \multirow{2}{*}{ suggestion } & PL & $c z y, c o$ & no $(2 / 3)$, follow-up $(1 / 3)$ & 2 & 5.33 \\
\hline & LV & kur, vai, kāpēc & follow-up $(1 / 2)$, no $(1 / 2)$ & 3 & 5.6 \\
\hline \multirow{2}{*}{ evaluation, accusatory } & PL & czy, dlaczego, jak + others & follow-up $(1 / 2)$, no $(1 / 2)$ & 4 & 18 \\
\hline & LV & vai, $k \bar{a} p \bar{e} c+$ others & follow-up $(1 / 2)$, no $(1 / 2)$ & 13 & 27.2 \\
\hline \multirow{2}{*}{ rhetorical } & PL & various & no, follow-up & 2 & 5.33 \\
\hline & LV & $k a s^{*}+$ others & no, follow-up & 0 & 6.4 \\
\hline \multirow{2}{*}{ ambiguous, unclassified } & PL & various & various & 3 & 10 \\
\hline & LV & various & various & 2 & 10.4 \\
\hline
\end{tabular}


Also, it shows some interesting differences between the amount of reaction requests and evaluatives in Polish and Latvian. In Polish, the former type is used over four times more often than in Latvian and it is the most common kind (together with token information questions) in this corpus. On the other hand, evaluatives are the most commonly used questions in Latvian, while reaction requests are very rare.

Another conclusion is that Latvian parliament allows for much more acute criticism and judgement. It is proven not only by the sole number of evaluative/accusatory questions, but also by the "strength" of evaluative phrases employed (the level of direct and indirect abuse is much higher here than in the PL Sejm). It is an interesting result, worth further investigation. The reason for it may be the fact that the Latvian parliament is divided into two "camps" (pro-Europeans and pro-Russians) that are in such a fierce conflict that many debates on any - also unrelated - topic reach out of the professional political sphere into the private sphere (ethnicity, nationality). And the need to protect and defend the private sphere is what makes speakers emotional. However, more profound studies must be conducted if this hypothesis is to be maintained.

\section{REFERENCES}

BRyant Gregory A., Fox Tree Jean E. 2002. "Recognizing Verbal Irony in Spontaneous Speech.” Metaphor and Symbol 17(2), 99-117.

Bybee Joan, Fleischman Susanne (eds.). 1995. Modality and Grammar in Discourse. Amsterdam: John Benjamins.

СамісіоттоLi Crawford B. 2008. "Interaction in Academic Lectures vs. Written Text Materials: The Case of Questions.” Journal of Pragmatics 40, 1216-1231.

Снолnicka Joanna. 2012. Linguistic Markers of Stance in Latvian Parliamentary Debates. PhD thesis. Saarbrücken: Lambert Academic Publishing.

Coulmas Florian (ed.). 1986. Direct and Indirect Speech. Berlin-New York-Amsterdam: Mouton de Gruyter.

FrajZYNGier Zygmunt. 1995. "A Functional Theory of Complementizers.” In: BybeE \& Fleischman 1995: 472502.

GoFFman Erving. 1967. Interaction Ritual. New York: Pantheon.

Horn Laurence R., WARD Gregory L. 2006. Handbook of Pragmatics. Oxford: Blackwell Publishing.

ILIE Cornelia. 1999. "Question-response Argumentation in Talk Shows." Journal of Pragmatics 31, 975-999.

ILIE Cornelia. 2010. "Strategic Uses of Parliamentary Forms of Address: The Case of the U.K. Parliament and the Swedish Riksdag.” Journal of Pragmatics 42, 885-911.

JAfFe Alexandra (ed.). 2009. Stance. Sociolinguistic Perspectives. Oxford: Oxford University Press.

Johnstone Barbara. 2009. "Stance, Style, and the Linguistic Individual.” In: JAFFE 2009: 29-52.

Koester Almut. 2006. Investigating Workplace Discourse. Domains of Discourse Series. London-New York: Routledge.

Kreuz Roger J. 2000. "The Production and Processing of Verbal Irony.” Metaphor and Symbol 15(1-2), 99-107.

ReXACH Javier G. 1998. "Rhetorical Questions, Relevance and Scales." Revista Alicantina de Estudios Ingleses 11: $139-155$.

SCHIFFrin Deborah. 1994. Approaches to Discourse. Oxford: Blackwell.

TANNEN Deborah. 1986. "Introducing Constructed Dialogue in Greek and American Conversational and Literary Narrative.” In: Coulmas 1986: 311-332. 